\title{
Phytochemical analysis and comparison of in-vitro antimicrobial activities of the leaf, stem bark and root bark of Ficus benghalensis
}

\author{
O.P OGUNLOWO ${ }^{*}$, B.D ARIMAH ${ }^{1}$, M.A ADEBAYO ${ }^{2}$ \\ ${ }^{I}$ Department of Pharmaceutical Microbiology, Igbinedion University Okada, Nigeria. \\ ${ }^{2}$ Pharmaceutical Phamacognosy Department, Igbinedion University Okada, Nigeria.
}

\begin{abstract}
In this study, the antimicrobial activities of aqueous extracts of leaf, bark and root bark of Ficus benghalensis plant were investigated against five bacteria (E.coli, S.aureus, B.subtilis, K.pneumoniae and P.aeruginosa and two fungi (T.rubrum and C.albicans). The results showed that the stem bark extract showed maximum antimicrobial activity on the five bacteria and two fungi used, K.pneumoniae and P.aeruginosa were resistant to the leaf and root extracts. C.albicans was also susceptible to all the extracts while T.rubrum was resistant to the leaf extract. Phytochemical screening showed the presence of Tannins, Flavonoids, Phenols, Saponins, Glycosides, Xanthoproteic, Carbohydrates and Alkaloids. There were various zones of inhibition in the antibiotics sensitivity of the bacteria used, while some were susceptible, others were not. The two fungi were also susceptible to Nystatin. The positive results for antimicrobial activities of the extract confirm the use of the plant in folk medicine in treatment of diverse ailments.
\end{abstract}

Keywords: Ficus benghalensis, phytochemical constituents, antimicrobial efficacy, dimethyl sulfoxide (DMSO), antibiotics

\section{INTRODUCTION}

Herbal medicine is the study and use of medicinal properties of plants. Plants have the ability to synthesize a wide variety of chemical compounds that are used to perform important biological functions ${ }^{[1]}$ and to defend against attack from predators such as insects, fungi and herbivorous mammals. Many of these phytochemicals have beneficial effects on long-term health when consumed by humans, and can be used to effectively treat human diseases. Chemical compounds in plants mediate their effects on the human body through processes identical to those already well understood for the chemical compounds in conventional drugs; thus herbal medicines do not differ greatly from conventional drugs in terms of how they work ${ }^{[2]}$. This enables herbal medicines to be as effective as conventional medicines, but also gives them the same potential to cause harmful side effects.

In 2001, researchers identified 122 compounds used in modern medicine which were derived from ethno medical plant sources ${ }^{[3]}, 80 \%$ of these compounds have had an ethno medical use identical to the current use of the active synthetic drugs ${ }^{[4]}$. Many of the pharmaceuticals currently available to physicians have a long history of use as herbal remedies, including aspirin, digitalis, and quinine, opium. The use of herbs to treat disease is almost universal among non-industrialized societies ${ }^{[5], ~[6]}$ and is often more affordable than purchasing expensive modern pharmaceuticals. Researchers found that people in different parts of the world tended to use medicinal plants for medical purposes. In the early 19th century, when chemical analysis first became available [7], [8], scientists began to extract and modify the active ingredients from plants. Later, chemists began making their own version of plant compounds and, over time, the use of herbal medicines declined in favour of drugs. Almost one fourth of pharmaceutical drugs are derived from botanicals.

The plant is a large evergreen tree distributed all over Southern and Eastern part of Nigeria but most common in deciduous forest South West. It is a grown in gardens and road sides for shades ${ }^{[9]}$. It is a member of four sacred trees meant to be planted around the home and temples. It is found throughout the year, grows in evergreen except in dry localities where it is a leafless for a short time. It is hardy and drought-resistant; it withstands mild frost. It is epiphytic when young. It develops from seeds dropped by birds on old walls or on other trees and is therefore, considered destructive to forest trees, walls and buildings ${ }^{[10]}$. The tree is commonly known as 'Opoto' in Yoruba, 'Banyan' tree in English, 'Bar' in Hindi and as 'Avaroha' in Sanskrit. The species of four Ficus yielding latex consist of Nyagrodha (Ficus bengalensis), Udumbara (Ficus glomerata/Ficus racemosa), Plaksha (Ficus lacor/Ficus retusa) and Ashvattha (Ficus religiosa) ${ }^{[11]}$ the bark and leaves of this group are used as astringent, haemostatic, anti-inflammatory, anti-septic; prescribed in diarrhoea, dysentery, and in the treatment of skin diseases, ulcers, vaginal disorders, leucorrhoea, menorrhagia, deficient lactation ${ }^{[2]}$. A 
very large tree up to $30 \mathrm{~m}$ in height leaves spirally arranged on branchlets up to $10-30 \mathrm{~cm}$ long and $7-20 \mathrm{~cm}$ wide, coriaceous, elliptic to ovate, apex obtuse, base rounded, with 5-7 basal nerves; petioles $2.5-5 \mathrm{~cm}$ long; stipules stout ${ }^{[13]}$. Fruits receptacles sessile, axillary in pairs $1.3-1.9 \mathrm{~cm}$ in diameter globose silky pubescent, scarlet or brick red when ripe; bracts $4-5$, copular, $6 \mathrm{~mm}$, shortly connate, obtuse persistent and sepals 3-5, Male flowers dispersed with female, stamen 1, another oblong, parallel, unequal, and shortly mucronate. Ovary-obovoid globose, $1.5 \times 1 \mathrm{~mm}$, style erects or curved, tapering, gall flowers similar to female, pedicellate, achnes globoseellipsoid, $2 \times 1.5 \mathrm{~mm}$ dark brown flowers during the summer and fruits the rainy season. Smooth bark, light greywhite, $1.27 \mathrm{~cm}$ thick wood moderately hard, grey or grayish-white ${ }^{[14]},{ }^{[15]}$. In the traditional system of medicine, the plant is used for various health problems and diseases.

\author{
Kingdom: Plantae \\ Sub Kingdom: Tracheobiota \\ Super division: Spermatophyta \\ Division: Magnoliophyta \\ Class: Magnoliopsida \\ Subclass: Hamamelidae \\ Order: Urticales \\ Family: Moraceae \\ Genus: Ficus \\ Species: Ficus benghalensis
}

Taxonomic classification of Ficus benghalensis

\title{
II. MATERIALS AND METHOD
}

\section{Collection of the plant materials}

The plant materials were collected in November 2012, at Okada in Edo State, Nigeria. The leaves, barks and roots were identified and authenticated by Mr. B.U Ikhile, Department of Phamacognosy, Igbinedion University Okada.

Preparation of the materials: - The materials were initially separated from the main plants body, rinsed with distilled water and air dried at room temperature in laboratory and then homogenized into fine particles and stored in air tight bottles and was used for all the extraction process.

\section{Extract Preparation}

Each of the dried pulverized powder (leaf, stem-bark and root-bark) was weighed $(600 \mathrm{~g})$ into a large beaker and filled up with $2000 \mathrm{ml}$ of cold water and covered, it was left un-interrupted for $24 \mathrm{hrs}$, it was sieved using muslin cloth followed by sterile filter paper into a sterile conical flask, the solution was subjected to hot air water bath evaporation at $35^{\circ} \mathrm{C}$, the crude extract was obtained and stored at $4^{\circ} \mathrm{C}$ for further use ${ }^{[16]}$.

The percentage yield of the crude aqueous extracts is calculated as follows

$\%$ yield $=\underline{\text { weight } \text { of extract }} \times 100$

weight of sample

$$
\text { Leaf }=\frac{12.47 \mathrm{~g}}{600 \mathrm{~g}} \times 100, \quad \text { Bark }=\frac{16.90 \mathrm{~g}}{600 \mathrm{~g}} \times 100, \quad \text { Root }=\frac{14.32 \mathrm{~g}}{600 \mathrm{~g}} \times 100
$$

\section{A. PHYTOCHEMICAL SCREENING OF PLANTS}

Phytochemical analysis of plants was carried out for all the extracts as per the standard methods.

\section{Detection of alkaloids:}

Extracts were dissolved individually in dilute Hydrochloric acid and filtered ${ }^{[17]}$. Filtrates were treated with Mayer's reagent (Potassium Mercuric Iodide). The yellow coloured precipitate was indicated that presence of alkaloids.

\section{Detection of carbohydrates:}

Extracts were dissolved individually in $5 \mathrm{ml}$ distilled water and filtered it. The filtrates sample was used to test for the presence of carbohydrates. Filtrates samples were hydrolyzed with the dilute $\mathrm{HCl}$, and neutralized with alkali then heated with Fehling's A and B solutions ${ }^{[18]}$. The red coloured precipitate indicated that presence of reducing sugars. 


\section{Detection of glycosides:}

Sample extracts were hydrolyzed with the dilute $\mathrm{HCl}$, and then subjected to test for glycosides.

\section{Detection of steroids and terpenoids}

In $1 \mathrm{ml}$ of methanol plant extract $1 \mathrm{ml}$ of chloroform was added and 2-3 $\mathrm{ml}$ of acetic anhydride was mixed then 1-2 drops of concentrated $\mathrm{H}_{2} \mathrm{SO}_{4}$ was added. Then dark green colouration of the solution indicated that the presence of steroids and pink or red colouration of the solution indicated that presence of terpenoid.

\section{Detection of saponins}

Froth Test: Extracts were diluted with distilled water to $20 \mathrm{ml}$ and this was shaken in a graduated cylinder for 15 minutes only. Then formation of $1 \mathrm{~cm}$ layer of foam indicated that presence of saponins.

Foam Test: $0.5 \mathrm{~g}$ of plant extracts was shaken with $2 \mathrm{ml}$ of water. The foam was produced persists for 10 minutes it was indicated that the presence of saponins.

\section{Detection of phenols}

Ferric Chloride Test: Extracts were treated with 3-4 drops of ferric chloride solution. The bluish black colour was indicated that presence of phenols.

\section{Detection of proteins and amino acids}

Xanthoproteic Test: The extracts were treated with few drops of concentrated nitric acid. Then the formation of yellow colour indicated that presence of proteins.

\section{Detection of flavonoids}

In Methanol extract $10 \% \mathrm{NaOH}$ was added and dilute $\mathrm{HCl}$ was added to that solution. The change of colour from yellow to colourless provides the positive result.

\section{B. ANTI-MICROBIAL TEST}

The microbial strains are standard which were obtained from University College Hospital, Ibadan. The bacterial strains studied were Bacillus subtilis, Klebsiella pneumonia, Pseudomonas aeruginosa, Escherichia coli and Staphylococcus aureus. The fungi used were Candida albicans and Trichophyton rubrum

\section{Bacterial cultures}

The overnight bacterial culture used was prepared by sub-culturing, a loopful was streaked with a sterile wire loop and inoculated into $5 \mathrm{ml}$ nutrient broth present in the test tubes and were incubated at $37^{\circ} \mathrm{C}$ for $24 \mathrm{hrs}$.

\section{Fungal cultures}

Fungal culture was prepared by streaking from fungal slopes with the aid of a sterile loop and inoculated into $5 \mathrm{ml}$ Tryptone soy broth present in the test tubes and incubated for $48 \mathrm{hrs}$.

\section{Preparation of Bacterial seeded plate}

Dilution of $0.2 \mathrm{ml}$ of $10^{-6}$ each of these cultures was introduced into $20 \mathrm{ml}$ molten Mueller Hilton agar in the bottles, it was mixed well and poured into plates and allowed to set. Four equidistant ditches were made on each plate of bacteria with the aid of cork borer $\{6 \mathrm{~mm}\}$, three wells were used for methanol extract (leave, stem-bark and root-bark) and the fourth well serves as control. This procedure was duplicated for the aqueous extract

\section{Preparation of Fungal seeded plate}

Dilution of $0.2 \mathrm{ml}$ of $10^{-6}$ each of the two cultures was introduced into $20 \mathrm{ml}$ molten potato dextrose agar in the bottles, it was mixed well and poured into plates and allowed to set. Four equidistant ditches were made on each plate of fungi with the aid of cork borer $\{6 \mathrm{~mm}\}$, three wells were used for methanol extracts (leave, stem-bark and root-bark) and the fourth well serves as control. This procedure was done in pairs for the aqueous extract

\section{Antimicrobial screenings}

The crude extract was reconstituted with $30 \mathrm{mg} / \mathrm{ml}$, each extract was screened for antimicrobial activity using the seeded bacterial and fungal plates. The method employed was agar diffusion ${ }^{[19]}$ technique in which the anti-microbial activities of different extracts from different partitions were placed in plates containing a single 
microorganism. $40 \mu \mathrm{l}$ of the extract was placed in the well with the use of pasture pipette. The plates were left on the bench for an hour at room temperature to allow diffusion of the extract into the agar. The plates were incubated at $37^{\circ} \mathrm{C}$ for $24 \mathrm{hrs}$ for bacteria and $30^{\circ} \mathrm{C}$ for $48 \mathrm{hrs}$ for fungi. The negative control used was DMSO ${ }^{[20]}$ for both fungi and bacteria and $50 \mu \mathrm{g} / \mathrm{ml}$ for Nystatin. After specified time of incubation, the plates were brought out of incubator and the diameter of zone of inhibition was measured with ruler calibrated in millimeters.

\section{Antibiotic sensitivity test}

To determine the antibacterial activity of standard antibiotics, the disc diffusion method was applied. Paper disc impregnated with antibiotics of known concentrations was placed on the surface of agar plate inoculated with the test organism with the aid of sterile forceps. The plates were incubated at $37^{\circ} \mathrm{C}$ for $24 \mathrm{hrs}$, the zone of inhibition was later observed around the disc.

\section{RESULTS AND DISCUSSION}

\section{ANTIMICROBIAL SENSITIVITY TEST}

Table III shows the inhibitory activity of the leaf, bark and root bark of Ficus benghalensis on the bacteria at $30 \mathrm{mg} / \mathrm{ml}$. The bark of the plant had more potency on bacteria than the other parts (i.e. leaf and root). $S$. aureus had the highest zone of inhibition in the bark and leaf. For the DMSO, there was no zone of inhibition on any of the bacteria used. Klebsiella pneumoniae had the lowest zone of inhibition in leaves and root bark extract.

\section{ANTIFUNGAL SENSITIVITY TEST}

Table IV shows the inhibitory activity of the leaf, bark and root bark extracts of Ficus benghalensis on the fungi used at $30 \mathrm{mg} / \mathrm{ml}$. The extracts also showed better potency on the fungi. No zone of inhibition in leaf aqueous extract of Trichophyton rubrum

\section{ANTIBIOTIC SENSITIVITY TEST}

The inhibitory effect of standard antibiotic disc of various concentrations tested on the bacteria was shown in Table V

\section{PHYTOCHEMICAL SCREENING OF EXTRACT}

Table II below indicates the phytochemical groups present in each sample

Table I PERCENTAGE EXTRACT YIELD

The percentage yield of the extracts

\begin{tabular}{|l|l|l|l|}
\hline EXTRACT & LEAF $(\%)$ & BARK $(\%)$ & ROOT $(\%)$ \\
\hline AQUEOUS & 2.078 & 2.817 & 2.387 \\
\hline
\end{tabular}

TABLE: II PHYTOCHEMICAL ANALYSIS OF THE EXTRACTS

\begin{tabular}{|l|l|l|l|}
\hline Group & Leaf & Bark & Root \\
\hline Alkaloids & + & - & + \\
\hline Carbohydrates & + & + & - \\
\hline Glycosides & + & + & + \\
\hline Terpenoids & + & + & + \\
\hline Saponins & + & + & + \\
\hline Phenols & + & + & + \\
\hline Xanthoproteic & + & + & - \\
\hline Flavonoids & + & + & + \\
\hline Tannins & + & + & + \\
\hline
\end{tabular}

KEYS

+ : Present

-: Absent 
Table III ANTIBACTERIAL SENSITIVITY TEST OF THE EXTRACTS

Note: Sensitivity at $30 \mathrm{mg} / \mathrm{ml}$

\begin{tabular}{|l|l|l|l|}
\hline \multicolumn{4}{|c|}{ AQUEOUS INHIBITION ZONE (MM) } \\
\hline EXTRACT & LEAF & BARK & ROOT \\
\hline E. coli & 10 & 19 & 15 \\
\hline S. aureus & 12 & 24 & 8 \\
\hline P. aeruginosa & $\mathrm{R}$ & 10 & $\mathrm{R}$ \\
\hline B. subtilis & 12 & 17 & 12 \\
\hline K. pneumoniae & $\mathrm{R}$ & 14 & $\mathrm{R}$ \\
\hline
\end{tabular}

ANTIFUNGAL SENSITIVITY TEST OF THE EXTRACTS

Table IV

\begin{tabular}{|l|l|l|l|l|}
\hline \multirow{2}{*}{ EXTRACT } & \multicolumn{3}{|c|}{ INHIBITION ZONE (MM) } & \\
\cline { 2 - 5 } & LEAF & BARK & ROOT & NYSTATIN \\
\hline C. albicans & 8 & 12 & 10 & 16 \\
\hline T.rubrum & R & 10 & 8 & 14 \\
\hline
\end{tabular}

KEY

Nystatin $=30 \mu \mathrm{g}$

$\mathbf{R}=$ Resistant

TABLE $\mathrm{V}$

ANTIBIOTICS SENSITIVITY TEST ON BACTERIAL ISOLATES

a) For Gram positive bacteria

\begin{tabular}{|l|l|l|l|l|l|l|l|l|l|l|}
\hline \multicolumn{9}{|c|}{ Antibiotics } \\
\hline Bacteria & PEF & CN & APX & Z & AM & R & CPX & S & SXT & E \\
\hline S.aureus & $\mathbf{R}$ & $\mathbf{R}$ & $\mathbf{R}$ & $\mathbf{R}$ & $\mathbf{R}$ & $\mathbf{R}$ & $\mathbf{7}$ & $\mathbf{R}$ & $\mathbf{R}$ & $\mathbf{R}$ \\
\hline B.subtilis & $\mathbf{6}$ & $\mathbf{R}$ & $\mathbf{R}$ & $\mathbf{R}$ & $\mathbf{R}$ & $\mathbf{5 . 5}$ & $\mathbf{5 . 5}$ & $\mathbf{5}$ & $\mathbf{R}$ & $\mathbf{R}$ \\
\hline
\end{tabular}

b) For Gram negative bacteria

\begin{tabular}{|l|l|l|l|l|l|l|l|l|l|l|}
\hline \multicolumn{10}{|c|}{ Antibiotics } & AM \\
\hline Bacteria & PEF & CN & SP & AU & AM & CH & CPX & S & SXT & OFX \\
\hline E.coli & $\mathbf{6 . 5}$ & $\mathbf{4}$ & $\mathbf{8}$ & $\mathbf{R}$ & $\mathbf{5}$ & $\mathbf{R}$ & $\mathbf{7}$ & $\mathbf{5 . 5}$ & $\mathbf{R}$ & $\mathbf{7 . 5}$ \\
\hline P.aeruginosa & $\mathbf{8 . 5}$ & $\mathbf{5 . 5}$ & $\mathbf{6 . 5}$ & $\mathbf{R}$ & $\mathbf{4 . 5}$ & $\mathbf{R}$ & $\mathbf{9 . 8}$ & $\mathbf{R}$ & $\mathbf{6 . 4}$ & $\mathbf{5}$ \\
\hline K.pneumoniae & $\mathbf{5 . 4}$ & $\mathbf{6 . 8}$ & $\mathbf{7 . 8}$ & $\mathbf{R}$ & $\mathbf{5}$ & $\mathbf{R}$ & $\mathbf{8 . 4}$ & $\mathbf{5}$ & $\mathbf{R}$ & $\mathbf{6 . 9}$ \\
\hline
\end{tabular}

KEY

$\mathbf{R}=$ Resistance

Full names of the antibiotics with their concentrations

\begin{tabular}{|l|l|l|l|}
\hline \multicolumn{2}{|c|}{ ANTIBIOTICS } & \multicolumn{1}{c|}{ Conc. (Gram +ve) } & \multicolumn{1}{c|}{ Conc. (Gram -ve) } \\
\hline PEF & Pefloxacin & $10 \mu \mathrm{g}$ & $30 \mu \mathrm{g}$ \\
\hline CN & Gentamycin & $10 \mu \mathrm{g}$ & $10 \mu \mathrm{g}$ \\
\hline APX & Ampiclox & $30 \mu \mathrm{g}$ & --- \\
\hline SP & Sparfloxacin & --- & $10 \mu \mathrm{g}$ \\
\hline Z & Zinacef & $20 \mu \mathrm{g}$ & --- \\
\hline AU & Augmentin & --- & $30 \mu \mathrm{g}$ \\
\hline AM & Amoxacillin & $30 \mu \mathrm{g}$ & $30 \mu \mathrm{g}$ \\
\hline R & Roceptin & $25 \mu \mathrm{g}$ & --- \\
\hline CH & Chloramphenicol & --- & $30 \mu \mathrm{g}$ \\
\hline CPX & Ciprofloxacin & $10 \mu \mathrm{g}$ & $10 \mu \mathrm{g}$ \\
\hline S & Streptomycin & $30 \mu \mathrm{g}$ & $30 \mu \mathrm{g}$ \\
\hline SXT & Septrin & $30 \mu \mathrm{g}$ & $30 \mu \mathrm{g}$ \\
\hline E & Erythromycin & $10 \mu \mathrm{g}$ & --- \\
\hline OFX & Tarivid & --- & $10 \mu \mathrm{g}$ \\
\hline
\end{tabular}

Phytochemical screening the extracts of leaf bark and root bark of F.bengalensis has been summarized in Table II. Tannins, Flavonoids, Phenols, Saponins and Glycosides were present in all the extracts. Xanthoproteic and Carbohydrates were present leaf and bark. The Alkaloids were present in leaf and root. This conforms to research demonstrated by Babu et al. (2010), in preliminary phytochemical screening of $F$. 
bengalensis ${ }^{[21]}$. They showed the presence Tannins, Saponins, Flavonoids, Terpenoids in all parts of F.bengalensis Alkaloids and

The leaf and root extracts had no antibacterial activity against P.aeruginosa and K. pneumonia, from the five bacterial strains investigated; the most susceptible bacterial strains were S.aureus and B.subtilis. E.coli was less susceptible. Gram-negative bacterial strains were more resistant than Gram-positive bacterial strains. Similarly, both the methanol and aqueous extracts had inhibitory activity against two fungi (C.albicans and T.rubrum) except for the aqueous leaf extract that was resistant to T. rubrum.

Most of the antibiotics were inhibitory on the test organisms except Septrin, Chloramphenicol and Augmentin on Gram negative. However, on Gram positive, S.aureus showed resistance to all antibiotics except Ciprofloxacin. On the other hand, B.subtilis was susceptible to Pefloxacin, Roceptin, Ciprofloxacin and Septrin.

\section{CONCLUSION}

Ficus benghalensis is an important medicinal plant that has a number of bioactive compounds. The aqueous extracts of the plant have revealed some potential phytochemicals like alkaloids, glycosides, Terpenoids, flavonoids, and tannins. The extracts had antimicrobial activity against selected microorganisms with the bark having the highest potency, this is very similar to commercial antibiotics indicating that bioactive compound from the plant can be used for the production of new antibiotics. However, it is imperative that more clinical and pharmacological studies should be conducted to investigate the unexploited potential of this plant.

\section{REFERENCES}

[1.] Mahalingam G, Krishnan K, antidiabetic and amelioferative potential of Ficus bengalensis bark extract in streptozotocin induced diabetic rats Indian Journal of Biochemistry;23(4):394-400, 2008.

[2.] Manoj Aswar, Urmila Aswar, Bhagyashri Watkar, Meenakshi Vyas, Akshaya Wagh, Kishore .N. Gujar, Anthelmintic activity of Ficus bengalensis, International Journal Of Green Pharmacy, 27: 170-172, 2008.

[3.] Achrekar S, Kaklaji GS, Pote MS, Kelkar SM. Hypoglycemic activity of Eugenia Jambolana and Ficus bengalensis: Mechanism of action. In vivo 5:143-7, 1991.

[4.] Patil V.V., Pimprikar R.B., Patil V.R. Pharmacognostical Studies and Evaluation of Anti-inflammatory Activity of Ficus bengalensis Linn JYP Vol 1, Issue 1, Jan-Mar, 2009;49-53.

[5.] Ananthanarayan R.T, C K J Panikar, Textbook of Microbiology, Orient Longman Limited, Madras, 6th ed. 1992; p. $370-373$.

[6.] Augusti KT. Hypoglycemic action of bengalenoside: A glucoside isolated from Ficus Bengalensis Linn, in normal and Alloxan diabetic rabbits. Indian J Physiology Pharmacology 1975, 19:218-20.

[7.] Bhadauria, K.K.S., Pailanbhadauri, G.H., Das, M.M., Kundu, S.S., Singh, J.P., and Lodhibhadauri, G.N., Evaluation of shrubs and tree leaves for carbohydrate and nitrogen fractions Indian: Journal of Animal Sciences 87-90, 2002.

[8.] Cherian S, Augusti K.T., To study the Antidiabetic effects of a glycoside of leucopelargonidin isolated from Ficus bengalensis Linn Indian J Exp Biol: 31(1):26- 29,1993.

[9.] Chattopadhyay, R.R., A comparative evaluation of some blood sugar lowering agents of plant origin. J Ethnopharmacol. 67: 367- 372. 1999.

[10.] Aiyegoro, A., and Okoh, A.I., Use of bioactive plant products in combination with standard antibiotics: implications in antimicrobial chemotherapy Journal of Medicinal Plants Research.1147-1152, 2009.

[11.] Barry A.L., The antimicrobial susceptibility test principles and practices, Lea and Febiger, Philadelphia, $1976 ;$ p.163-164.

[12.] Duguid J.P., B.P. Marmion, R. H. A. Swain, MACKIE \& Mc CARTNEY Medical Microbiology, Vol 1, microbial infections, 13th ed. Churchill Livingstone, 1980; p.304.

[13.] Hales BF, Comparison of the mutagenicity and teratogenicity of Cyclophosphamide and its active metabolites, 4hydroxycyclophosphamide, phosphoramide mustard and acrolein. Can. Res., 42: 3016-3021, .2010.

[14.] Michael J. Pelczar JR., E.S.C. Chan, Noel. R. Krieg, Microbiology, Tata McGraw-Hill publishing, 5th ed. 1997; p. $274-275$.

[15.] Hayashi M, Tice RR, Macgregor JT, Aderson D, Blakey DH, In vivo rodent erythrocyte micronucleus assay. Mutation Research. 312: 293-304, .2011.

[16.] De Flora S, Izzotti A, Mutagenesis and Cardiovascular diseases: molecular mechanisms, risk factors, and protective factors. Mut. Res., 621: 5-17 2007.

[17.] Julian Preston, R., Brian J. Dean, Sheila Galloway, Henry Holden, Alfred F. Me Fee, and Michael Shelby, "Mammalian in vivo cytogenetic assays, Analysis of chromosomal aberrations in mouse bone marrow cells", Mutation Research, 189(12):67-89, 2005 .

[18.] Meera S, Nagarjuna CG (2009). Antistress and immunomodulatory activity of aqueous extract of Momordica charantia. Pharmacognosy Magazine, 5(19): 69-73.

[19.] Rajib Ghosh, Sharathchandra.Kh., Rita .S., Thokchom I.S., Hypoglycemic activity of Ficus hispida (bark) in normal and diabetic albino rats, Indian Journal of Pharmacology, 36(4), pg436 2004.

[20.] Rout .S. D., Panda.T. Mishra.N, Ethno-medicinal plants used to cure different diseases by tribal of Mayurbhanj district of North Orissa, Ethno-Med, 3(1), pg.: 27-32, 2009.

[21.] Babu Faten MM. Phytochemical study of Ficus bengalensis L. Bull. Fac. Pharm. (Cairo Univ.), 40(2): $249-258,2002$.

[22.] Akhtar, M. S., Iqbal, Z., Khan, M. N., and Lateef, M., Anthelmintic activity of medicinal plants with particular reference to their use in animals in the indo-Pakistan subcontinent. Small Ruminant Research 99-107, 2000. 